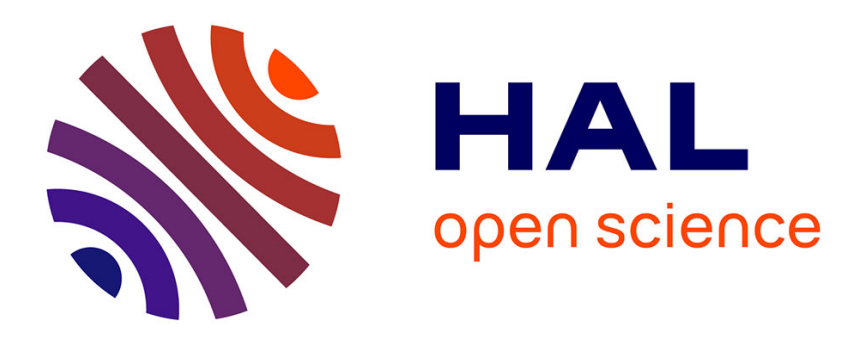

\title{
Vivre en prison à l'époque abbasside
}

Mathieu Tillier

\section{To cite this version:}

Mathieu Tillier. Vivre en prison à l'époque abbasside. Journal of the Economic and Social History of the Orient, 2009, 52, pp.635-659. halshs-00565462

\section{HAL Id: halshs-00565462 \\ https://shs.hal.science/halshs-00565462}

Submitted on 13 Feb 2011

HAL is a multi-disciplinary open access archive for the deposit and dissemination of scientific research documents, whether they are published or not. The documents may come from teaching and research institutions in France or abroad, or from public or private research centers.
L'archive ouverte pluridisciplinaire HAL, est destinée au dépôt et à la diffusion de documents scientifiques de niveau recherche, publiés ou non, émanant des établissements d'enseignement et de recherche français ou étrangers, des laboratoires publics ou privés. 


\title{
VIVRE EN PRISON À L'ÉPOQUE ABBASSIDE
}

par

\author{
Mathieu Tillier
}

\begin{abstract}
Résumé : Nous proposons dans cet article d'examiner les conditions de vie dans les prisons à l'époque abbasside. Le croisement des chroniques, des dictionnaires biographiques, de l'adab et de la littérature juridique permet de reconstituer les principales caractéristiques de l'univers carcéral. Il apparaît que les détenus n'étaient entretenus qu'a minima par l'institution carcérale et dépendaient dans une large mesure de leurs familles ou de la charité publique. La promiscuité, la faim et la saleté, d'un degré comparable dans les prisons du pouvoir politicomilitaire et dans celles des cadis, contribuait au châtiment des malfaiteurs dans les premières et à la pression exercée sur les débiteurs dans les secondes.
\end{abstract}

Abstract: In this article, we investigate the conditions of life in jail under the Abbasids. A comparative study of chronicles, biographical dictionaries, $a d a b$ and legal literature allows a reconstruction of the main features of prison life. We argue that prisoners were supplied with the bare necessities by the prison institution and highly depended on their relatives or on public charity. The degree of promiscuity, hunger and dirtiness was quite similar in the politico-military prisons and in those of $q \bar{a} d \bar{l} s$; in the first type of jail it played a major role in the criminals' punishment, in the second one it was part of the pressure put on debtors.

Keywords: prison, law, punishment, Abbasids, daily life.

Nous sommes sortis de ce bas monde tout en y demeurant; Nous n'appartenons ni aux vivants ni aux morts. Si le geôlier vient nous trouver, un jour, pour quelque chose, Nous nous exclamons, stupéfaits : «Il nous vient du bas monde ! ${ }^{1}$

Prisonnier anonyme

Le quotidien des prisons dans l'Islam médiéval est peu connu. La structure des bâtiments carcéraux, l'entretien matériel des détenus, leurs conditions de vie et leur destin après leur mort demeurent jusqu'ici dans l'ombre. Ces dernières années, notre appréhension de l'univers carcéral s'est pourtant considérablement améliorée. Dans une étude pionnière, Irene Schneider a décrit les principales utilisations de la prison à l'époque classique ${ }^{2}$; une analyse des sources juridiques l'a notamment conduite à distinguer le sort des débiteurs et des

\footnotetext{
${ }^{1}$ Ibn Qutayba, 'Uyūn al-akhbār, éd. Muhammad al-Iskandarānī (Beyrouth : Dār al-kitāb al-'arabī, 1994), 1 : 121.

${ }^{2}$ Schneider, «Imprisonment in Pre-classical and Classical Islamic Law », Islamic Law and Society 2 (1995) : 157-73. Une version condensée en est produite par le même auteur dans l'article «Sidjn », $E I^{2}, 9: 547$. Sur les prisons dans l'histoire de l'Islam, voir également H. 'A.-Gh. Abū Ghudda, Ahkām al-sijn wa-mu àmalat alsujanā' fì l-islām, Thèse de doctorat (Tunis : Université de la Zîtūna, 1986) ; B. Martel-Thoumian, « De l'équité à l'arbitraire : état des prisons et des prisonniers sous les derniers Mamlouks », Annales Islamologiques 40 (2006) : 205-46 ; N. Hentati, «La prison en Occident musulman médiéval », Arabica 54 (2007) : 149-88 ; M. Tillier, «Prisons et autorités urbaines sous les Abbassides », Arabica 55 (2008) : 387-408; Ch. Lange, Justice, Punishment, and the Medieval Muslim Imagination (Cambridge : Cambridge University Press, 2008) : 89-94.
} 
criminels qui, en théorie, ne devaient pas subir les mêmes conditions de détention ${ }^{3}$. La situation extrême de détenus politiques comme ceux du Muṭbaq, à l'époque abbasside, est également connue ${ }^{4}$. Il reste à déterminer quelles étaient les conditions de vie dans les prisons ordinaires.

Généralement avares en renseignements sur l'histoire du petit peuple et des bas-fonds, les sources arabes sont pourtant riches en informations sur les détenus. Les prisons de l'Islam constituaient en effet un milieu hétérogène, accueillant tant des truands que des marchands en faillite, des courtisans en disgrâce ou des sharïf-s suspects de déloyauté qui, pour leur part, ont pu retenir l'attention des chroniqueurs ou des biographes. Bien que l'existence de plusieurs types de prisons ${ }^{5}$ eût dû, en théorie, séparer les diverses catégories de détenus, la frontière n'était pas étanche et des membres de la haute société pouvaient être confrontés à des conditions de détention comparables à celles d'autres catégories. Souvent concises et disséminées dans divers types de sources, de nombreuses informations relatives aux prisons ont pu être réunies grâce aux outils électroniques aujourd'hui à la disposition des chercheurs ${ }^{6}$. Sans prétendre à l'exhaustivité ${ }^{7}$, les données ainsi récoltées permettent de reconstituer un tableau représentatif de la vie carcérale à l'époque abbasside. Au sein du large échantillon textuel examiné, nous avons sélectionné pour cet article le matériau relatif à l'Orient abbasside (132/750-334/945) ${ }^{8}$.

Quelques sources se distinguent par l'abondance ou la qualité de leurs informations sur l'univers carcéral. Les chroniques - au premier rang celle d'al-Ṭabarī (m. 310/923) évoquent souvent des prisonniers haut placés ou des événements liés à une prison. L'emprisonnement de savants pour dette ou délit d'opinion est par ailleurs relaté dans certains dictionnaires biographiques. En raison de leur sujet, les Maqātil al-Ṭālibiyīn d'al-Iṣfahānī (m. 356/967) - dédiés aux 'Alīdes persécutés par le pouvoir - et les dictionnaires consacrés aux cadis - comme les Ahbār al-quḍāt de Wakī' (m. 306/918) - ont particulièrement retenu notre attention. À travers les topos qu'elle véhicule, la littérature d'adab abbasside permet d'affiner l'image que prenait la prison dans le regard des contemporains ${ }^{9}$. Bien qu'elles soient souvent laconiques quant aux conditions d'incarcération - le Kitāb al-kharāj d'Abū Yūsuf (m. 182/798) représentant une exception notable -, les recommandations des sources juridiques ont été croisées, le cas échéant, avec les données des sources narratives. Au-delà des

\footnotetext{
${ }^{3}$ Schneider, «Imprisonment »: 169.

${ }^{4}$ Tillier, « Prisons et autorités urbaines » : 403-6; Abū Ghudda, Aḥkām al-sijn : 294 sq.

${ }^{5}$ Les prisons de cadis étaient principalement destinées à recevoir des débiteurs; les voleurs et les criminels étaient enfermés dans celles des autorités politico-militaires. Sur cette distinction, voir I. Schneider, « Imprisonment in Pre-classical and Classical Islamic Law » : 158 sq, 169.

${ }^{6}$ Cet article se fonde sur les données rassemblées au terme d'une recherche systématique préliminaire, dans la bibliothèque virtuelle al-Warrāq, des termes «sijn», «sujūn», «masjūn( $\bar{u} n / \bar{i} n) », ~ « m u s a j j a n(\bar{u} n / \bar{i} n) »$,

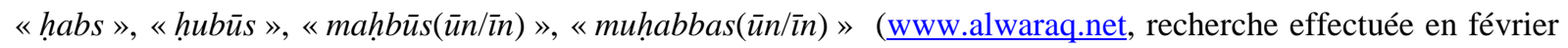
2007). Les sources juridiques, quasi-absentes sur le site al-Warrāq, ont été dépouillées de manière traditionnelle.

${ }^{7}$ L'augmentation des ressources virtuelles, incorporant un nombre de sources toujours plus élevé, permettra certainement l'obtention de résultats plus précis d'ici quelques années.

${ }^{8}$ Nous nous permettrons à titre exceptionnel de franchir les limites imparties à cette étude lorsqu'un élément extérieur à ce cadre chronologique apparaîtra comme particulièrement significatif.

${ }^{9}$ C'est notamment le cas des œuvres d'al-Jāḥiz (m. 255/868-69) et d'Ibn Qutayba (m. 276/889).
} 
conditions de détentions, un tel rapprochement entre ces divers types de sources permet de mieux appréhender les fonctions de la prison dans l'Islam médiéval.

Comme souvent, les lieux communs et les recompositions littéraires peuvent être soupçonnés d'occulter la réalité historique : l'image que les sources reflètent des prisons est en partie projetée par leurs auteurs. De telles représentations ne doivent pourtant pas être négligées, car les auteurs tentaient de convaincre leurs lecteurs/auditeurs de la véracité de leurs récits : pour atteindre leur but, ceux-ci devaient se couler dans les représentations de leur public, elles aussi liées aux réalités de leur temps ${ }^{10}$. Aussi doit-on postuler la relative vraisemblance de cette image, pour peu qu'elle provienne de sources assez proches de l'époque étudiée.

L'organisation des prisons est traditionnellement attribuée à l'Umayyade 'Umar II, à la politique carcérale duquel Ibn Sa d (m. 230/845) consacre le passage suivant :

Muhammad b. 'Umar nous rapporta d'après Mūsā b. 'Ubayda :

'Umar b. 'Abd al-'Azīz donna des instructions écrites pour que l'on contrôle les prisons et que l'on enferme étroitement les vauriens (ahl al-dha 'ārāt); il décida également de la subsistance (rizq) à leur distribuer en été comme en hiver.

Mūsā dit :

Je les vis, chez nous, recevoir chaque mois leur subsistance. On leur fournissait un vêtement en hiver et un autre en été.

Muḥammad b. 'Umar nous rapporta d'après Yahyyā b. Sa 'īe mawlā d'al-Mahrī :

'Umar b. 'Abd al-'Azīz écrivit aux émirs des jund-s : "Contrôlez ceux qui, dans les prisons, ont été condamnés ; n'emprisonne personne avant de l'avoir condamné. Si un cas pose problème, écris-moi à son sujet. Enferme étroitement (istawthiq) les vauriens : en prison, ils doivent être mis aux fers. N'inflige pas de châtiments excessifs. On doit prendre soin des malades seuls et désargentés. Lorsque tu emprisonnes des gens pour dette, ne les mets ni dans la même cellule (bayt) ni dans la même prison que les vauriens. Instaure une prison réservée aux femmes. Contrôle les responsables de ta prison, qui doivent être dignes de confiance et incorruptibles : celui qui se laisse corrompre fait ce qu' on lui ordonne. »

Muḥammad b. 'Umar nous rapporta d'après 'Amr b. 'Abd Allāh, d'après 'Abd Allāh b. Abī Bakr :

'Umar b. 'Abd al-'Azīz écrivit à Abū Bakr b. 'Amr b. Hazm ${ }^{11}$ de passer en revue les prisonniers tous les samedis et d'enfermer étroitement les vauriens.

Muḥammad b. 'Umar nous rapporta d'après Qays, d'après al-Ḥajjāj :

'Umar b. 'Abd al- 'Azīz écrivit à 'Abd al-Ḥamīd à propos des vauriens [pour lui demander] de les maintenir en prison, de leur fournir une cape $(t \bar{a} q)$ en hiver et deux habits en été, et lui prescrire telle et telle chose dans leur intérêt.

Muhammad b. 'Amr nous rapporta d'après Mūsā b. Muhammad, d'après Abū Bakr b. 'Amr b. Hazm :

'Umar b. 'Abd al-'Azīz m'écrivit de tenir les vauriens enchaînés ( $f i$ withāq), ainsi que les criminels (ahl al-dam). Je lui écrivis pour lui demander : «Comment peuvent-ils faire la prière tout en étant aux fers?» 'Umar me répondit : «Si Dieu le voulait, il leur infligerait bien plus que

\footnotetext{
${ }^{10}$ Cf. F.M. Donner, Narratives of Islamic Origins (Princeton : The Darwin Press, 1998) : 210.

${ }^{11}$ Cadi de Médine en 87/706, puis gouverneur de la même ville sous le califat de 'Umar II. Al-Ṭabarī, Ta'rīkh al-rusul wa'l-mulūk, éd. Muhammad Abū al-Faḍl Ibrāhīm (Le Caire : Dâr al-ma'ārif, 1967), 6 : 433 ; Wak̄'`, Akhbār al-quḍāt, éd. 'Abd al- 'Azīz Mușțafā al-Marāghī (Le Caire : Maṭba at al-sa āda, 1947-1950), 1 : 135, 148.
} 
les fers! Qu'ils prient comme ils le peuvent: ils ont une excuse. Quant aux chaînes, j'ai vu qu'Abū Bakr - Dieu ait son âme! - avait écrit qu'on lui envoie plusieurs hommes enchainés ; parmi eux se trouvait Qays b. Makshūh al-Murādī ${ }^{12}$ et d'autres personnes ${ }^{13}$.

L'authenticité de telles instructions importe peu ici. Leur attribution à un calife modèle, adulé pour sa piété et reconnu comme un souverain législateur ${ }^{14}$, révèle en revanche quelques préoccupations de la première moitié $\mathrm{du} \mathrm{III}^{\mathrm{e}} / \mathrm{IX}^{\mathrm{e}}$ siècle concernant les prisons. Deux thèmes principaux en ressortent : l'autorité sur les prisons et le contrôle de l'administration carcérale, et surtout le traitement des détenus et la vie quotidienne en prison. La question de l'autorité ayant fait l'objet d'un précédent article ${ }^{15}$, nous proposons d'aborder ici la vie quotidienne des détenus à travers trois aspects essentiels : habiter en prison, y satisfaire ses besoins vitaux ou ses obligations rituelles, et y mourir.

\section{Habiter en prison}

\subsection{La population carcérale}

Il est difficile d'évaluer la dimension des établissements carcéraux à l'époque abbasside. Les principales prisons de Bagdad ${ }^{16}$ ou la «grande prison» de Samarra ${ }^{17}$ accueillaient probablement un nombre élevé de détenus, mais on ne peut proposer qu'un ordre de grandeur. Al-Mubarrad affirme qu'en 54/684, lors de la révolte de Nāfi ‘ b. al-Azraq ${ }^{18}$, la prison de Bașra contenait 400 khārijites ${ }^{19}$. À la fin de l'époque umayyade, une prison égyptienne accueillait plus de 300 détenus $^{20}$. Un siècle plus tard, en 235/849, un incendie ravagea la prison de Bāb al-Shām, à Bagdad ${ }^{21}$, faisant 130 victimes ${ }^{22}$. Aux premiers siècles de l'Islam, certaines prisons semblaient donc accueillir plusieurs centaines de détenus. Les établissements carcéraux étaient-ils toujours adaptés à de tels chiffres ? On peut en douter. À la fin du II $/ \mathrm{VIII}^{\mathrm{e}}$ siècle, Abū Yūsuf évoque un problème de surpopulation : les prisonniers sont trop nombreux, affirme-t-il, car les autorités judiciaires n'examinent pas leur cas ou enferment les criminels au lieu d'appliquer les peines corporelles légales (hudūd). Il recommande que les représentants du calife (les wulāt, probablement tant les gouverneurs que les cadis) tiennent chaque jour audience pour juger les détenus, leur infliger un châtiment si nécessaire et les

\footnotetext{
${ }^{12}$ Aussi appelé Qays b. Hubayra al-Bajalī (m. 37/657). Sur ce compagnon du Prophète, voir Hु.-D. al-Ziriklī, alA 'lām (Beyrouth : Dār al- 'ilm li-l-malāyīn, 1997), 5 : 209.

${ }^{13}$ Ibn Sa d, al-Ṭabaqāt al-kubrā (Beyrouth : Dār Sādir, 1968), 5 : 356-57.

${ }^{14}$ P. Crone et M. Hinds, God's Caliph (Cambridge : Cambridge University Press, 1986) : 48.

${ }^{15}$ Tillier, « Prisons et autorités urbaines ».

${ }^{16}$ Voir Tillier, « Prisons et autorités urbaines » : $400 s q$.

${ }^{17}$ Voir A. Northedge, The Historical Topography of Samarra (Londres : British School of Archaeology in Iraq Fondation Max van Berchem, 2005) : 109, 110.

${ }^{18}$ Voir A. J. Wensinck, «Nāfi ' b. al-Azrak », $E I^{2}, 7: 877$.

${ }^{19}$ Al-Mubarrad, al-Kāmil, éd. Muhammad Aḥmad al-Dālī (Beyrouth : Mu'assasat al-risāla, 1997), 4 : 1212.

${ }^{20}$ Severus ben el-Moqaffa', Historia Patriarcharum Alexandrinorum, éd. C.F. Seybold (Paris: Carolus Poussielgue, 1904), 1: 181.

${ }^{21}$ Sur cette prison, voir Tillier, «Prisons et autorités urbaines » 401.

${ }^{22}$ Ibn al-Jawzī, al-Muntazam, éd. Suhayl Zakkār (Beyrouth : Dār al-fikr, 1995), $6: 436$. Le texte ne dit pas si toutes les victimes étaient des détenus, ce qui est néanmoins probable.
} 
libérer ${ }^{23}$. Peut-être ce problème de surpopulation était-il aggravé par l'inadéquation des locaux : tant les sources textuelles que l'archéologie attestent que la plupart des prisons étaient aménagées dans d'anciens bâtiments dont ce n'était pas la vocation originelle, notamment des palais ${ }^{24}$.

\subsection{Les bâtiments carcéraux}

$\mathrm{Au}$ sein des établissement carcéraux, la séparation sexuelle des prisonniers semblait de rigueur $^{25}$. En 251/865, en pleine guerre pour le contrôle du pouvoir à Samarra, al-Ṭabarī mentionne l'existence à Bagdad d'une «prison des femmes » (sijn al-nisā') et d'une «prison des hommes » $\left(\right.$ sijn al-rijāl ${ }^{26}$. Des juristes hanafites comme al-Khașșāf (m. 261/874) et alJașșāṣ (m. 370/980), qui réfléchissent au traitement judiciaire des femmes libres - dont le contact avec la société masculine devait être aussi limité que possible ${ }^{27}-$, ne semblent pourtant pas s'être penchés sur la séparation sexuelle des détenus. Peut-être une telle séparation était-elle suffisamment appliquée pour qu'il soit inutile d'aborder le sujet ${ }^{28}$. En revanche, au V⿳/XI ${ }^{\mathrm{e}}$ siècle, al-Simnān̄̄ (m. 449/1105-1106) préconise explicitement que les femmes disposent de leur propre prison, dirigée par une femme de confiance capable de gérer les affaires féminines ${ }^{29}$. Le hanafite al-Sarakhsī (m. 483/1090) demande également que les femmes incarcérées pour dette soient enfermées seules, à l'écart des hommes ${ }^{30}$.

Certains détenus privilégiés et de haut rang étaient sans doute enfermés dans des cellules individuelles, ou avec un nombre réduit de codétenus. L'Imam Ibrāhīm, chef secret de la da'wa abbasside, fut emprisonné à Harrān dans une pièce (hujra) séparée de celle où se trouvait un autre de ses compagnons ${ }^{31}$. En 219/834, le révolté Muhammad b. al-Qāsim al'Alawī fut enfermé pendant trois jours dans une très étroite cellule, avant d'être transféré dans une prison plus large ${ }^{32}$. Le plus souvent, néanmoins, l'incarcération semblait collective, plusieurs prisonniers étant réunis dans une même pièce (bayt) de dimension variable. Tel était le cas dans le Muṭbaq, principale prison de Bagdad jusqu'à la fin $\mathrm{du}_{\mathrm{III}}^{\mathrm{e} / \mathrm{IX}^{\mathrm{e}}}$ siècle $^{33}$. Sous al-

\footnotetext{
${ }^{23}$ Abū Yūsuf, Kitāb al-kharājj, éd. Mahmūd al-Bājī (Tunis : Dār Bū Salāma, 1984) : 152 (trad. E. Fagnan, dans Abou Yousof Ya koub, Le Livre de l'impôt foncier (Paris : Paul Geuthner, 1921) : 233).

${ }^{24}$ Voir Tillier, «Prisons et autorités urbaines » : 398 ; Northedge, The Historical Topography : 114.

${ }^{25}$ F. Rosenthal, The Muslim Concept of Freedom Prior the Nineteenth Century (Leyde : Brill, 1960) : 60 ; Abū Ghudda, Ahkām al-sijn : 254.

${ }^{26}$ Al-Ṭabarī, Ta'rīkh al-rusul wa'l-mulūk, $9: 250$.

${ }^{27}$ Selon al-Khașsāâ, le cadi devait réserver un jour particulier pour l'audition des plaintes des femmes afin de préserver leur réputation; une femme poursuivie pour dette et objet d'une mulāzama devait par ailleurs être suivie par une femme, et non par un homme. Al-Khașsạaf, Adab al-qāadì, éd. Farḥāt Ziyāda (Le Caire : The American University in Cairo Press, 1978) : 54, 264.

${ }^{28} \mathrm{La}$ mixité fut néanmoins possible dans certaines circonstances. Sawīrus b. al-Muqaffa' mentionne que des hommes et des femmes furent incarcérés ensemble en Égypte à la fin de l'époque umayyade. Severus ben elMoqaffa', Historia Patriarcharum Alexandrinorum, 1: 181.

${ }^{29}$ Al-Simnānī, Rawḍt al-quḍāt wa-țarīq al-najāt, éd. Salāḥ al-Dīn al-Nāhī, (Beyrouth-Amman : Mu'assasat alrisāla-Dār al-furqān, 1984), 1:133.

${ }^{30}$ Al-Sarakhsī, al-Mabsūt (Beyrouth : Dār al-ma' rifa, 1406 H.), 20 : 90.

${ }^{31}$ Al-Balādhurī, Ansāb al-ashrāf, éd. Suhayl Zakkār et Riyāụ Ziriklī (Beyrouth : Dār al-fikr, 1996), 4 : 165.

${ }^{32}$ Al-Ṭabarī, Ta'rīkh al-rusul wa'l-mulūk, 9 : 7.

${ }^{33}$ Sur cette prison, voir Tillier, « Prisons et autorités urbaines » : 403 sq.
} 
Manșūr, Ya 'qūb b. Dā'ūd y fut enfermé avec des prisonniers 'alīdes ${ }^{34}$, tout comme 'Alī b. alHasan b. al-Hasan ${ }^{35}$; sous al-Rashīd, le révolté 'alīde Yahyā b. 'Abd Allāh ${ }^{36}$ y partageait une étroite cellule (bayt) avec d'autres compagnons d'infortune ${ }^{37}$. À la même époque, à Fusțāt, le cadi al- 'Umarī fut emprisonné « avec plusieurs de ses compagnons » ${ }^{38}$.

Le caractère collectif de la détention entraînait une forte promiscuité. Al-Jāḥiz raconte avec humour qu'à l'époque umayyade, le gouverneur Mālik b. Asmā' (m. vers 100/718) ${ }^{39}$ fut emprisonné à Kūfa pendant un temps et dut subir la volubilité du codétenu assis à ses côtés ${ }^{40}$. Mais cette «promiscuité verbale »n'était rien en comparaison de la promiscuité physique. Le récit que le poète Abū l- Atāhiya (m. v. 210/825) aurait fait de son entrée en prison, sous alMahdī, est un des plus évocateurs :

À mon entrée, je fus frappé de stupeur devant le spectacle effrayant qui s'offrait à mes yeux. Je cherchais du regard un endroit pour m'installer, ou quelqu'un près de qui m'asseoir, quand j'aperçus un homme d'âge mûr à l'apparence agréable, aux vêtements propres et au visage avenant. Je me dirigeai vers lui et m'assis à ses côtés sans le saluer ni rien lui demander, tant j'étais effrayé et désemparé ${ }^{41}$.

Cette description suggère que la pièce dans laquelle entre le poète est peuplée d'une foule d'individus à l'aspect repoussant, dont la densité laisse peu de choix quant à l'endroit où le nouvel arrivant va pouvoir s'installer. La promiscuité physique résultant d'une telle densité est illustrée par al-Tawhị̄ī (m. 414/1023) dans une histoire du légendaire Juhāa :

On mentionna le pétomane (al-darrāt ) devant Juhāā, en disant : - «C'est une calamité !»«En quoi est-ce une calamité ?» demanda [Juḥā]. - « [Le péteur] divise les assemblées et disperse les réunions », répondit-on. - «C'est faux ! s'exclama-t-il. Les prisonniers (ahl al-sijn) pètent nuit et jour, et ne se dispersent pas pour autant $! »{ }^{42}$

Mais le désagrément des flatulences collectives pesait bien peu par rapports aux réels dangers de la prison. L'histoire d'Abū l- 'Atāhiya reflète non seulement l'horreur du courtisan face à la saleté de ses compagnons d'infortune, mais également la menace physique que cette cellule faisait peser sur lui. Dans le récit d'al-Ișfahānī, l'homme auprès de qui se réfugie le poète contraste avec le tableau indescriptible de ce qui l'entoure : sa propreté s'oppose à la saleté des autres, son air bon enfant à leurs faces de brutes. C'est qu'Abū l-'Atāhiya se retrouve soudain au milieu de truands. La prison où il est conduit, précise al-Iṣfahānī, est celle

\footnotetext{
${ }^{34}$ Al-Ṭabarī, Ta'rīkh al-rusul wa-l-mulūk, $7: 607$.

35 Al-Ișfahān̄i, Maqātil al-Ṭālibiyyīn, éd. Aḥmad Șaqr (Beyrouth : Mu'assasat al-a lāmī li-l-mațbū āt, 1987) : 176-77.

${ }^{36}$ Voir voir W. Madelung, « Yahyyā b. 'Abd Allāh », $E I^{2}, 11: 242$

${ }^{37}$ Al-Ișfahān̄̄, Maqātil al-Țālibiȳ̄n : 402.

${ }^{38}$ Al-Kindī, Akhbār quḍāt Miṣr, dans Kitāb al-wulāt wa-kitāb al-quḍāt, éd. R. Guest (Leyde : Brill, 1912$)$ : 412. Cf. Abū Ghudda, Ahkām al-sijn : 276.

${ }^{39}$ Voir al-Ziriklī, al-A ' lām, $5: 258$.

${ }^{40}$ Al-Jāḥiž, al-Bayān wa-l-tabȳ̄n, éd. 'Abd al-Salām Hārūn (Tunis : Dār Saḥnūn, 1990), 2 : 181.

${ }^{41}$ Al-Iṣfahānī, Maqātil al-Ṭālibiȳin : 359. Voir de même al-Tanūkhī, al-Faraj ba 'd al-shidda, éd. 'Abbūd alShāljī (Beyrouth, 1971-73), $2: 116$.

${ }^{42}$ Al-Tawhīīī, al-Baṣā'ir wa-l-dhakhā'ir, éd. Wadād al-Qāḍī (Beyrouth : Dār șādir, 1988), 5 : 106.
} 
des «criminels » (sijn al-jarā'im ${ }^{43}$ : non pas celle du cadi, surtout peuplée d'honnêtes débiteurs insolvables, mais celle des autorités politico-militaires (à Bagdad, principalement le șăhib al-shurța). À Damas, en 183/799, le chrétien Antoine Ruwah aurait été emprisonné au milieu de bandits, «subissant de leur part beaucoup de souffrances » ${ }^{44}$. Bien que nécessaire à la construction hagiographique de cette vie de saint, ce topos reflète une situation historique récurrente. $\mathrm{Au} \mathrm{III} / \mathrm{IX}^{\mathrm{e}}$ siècle, le ḥanafite al-Khașșāf met en garde contre les dangers de telles prisons, qu'il appelle pour sa part «prisons des voleurs » (sijn al-luṣūss); il recommande de ne pas y enfermer les débiteurs, à moins que leur propension à s'évader n'oblige le cadi à les placer dans de tels établissements de haute sécurité ${ }^{45}$.

\subsection{Le mobilier}

Le mobilier des prisons semblait très réduit. En 140/758, le 'Alīde 'Abd Allāh b. al-Ḥasan fut incarcéré à Médine. Trois sacoches (haqā’ib) de chameaux remplies de paille (tibn) lui furent apportées, probablement pour lui servir de couche. Lorsque sa femme lui rendit visite, elle le trouva accoudé à un bât ${ }^{46}$, ce qui complète l'image d'une prison différant peu, par son mobilier, d'une simple écurie. Un inconfort comparable régnait vers la même époque à Kūfa, dans la prison du cadi Sharīk b. 'Abd Allāh (en poste de 153/770 à 170/786 environ). Le gouverneur de la ville refusa un jour de répondre à une convocation du tribunal. Furieux, Sharîk fit emprisonner le chef de la police qui lui avait porté le refus de l'émir. Mais ledit chef de la police, anticipant cette réaction, avait auparavant fait porter à la prison un matelas (firāsh) et divers objets susceptibles d'améliorer son confort ${ }^{47}$. De ce point de vue, les «prisons de cadis»n'offraient pas de meilleures conditions de détention que celles des « criminels ».

Le traitement de certains prisonniers de haut rang faisait probablement exception. En 127/744, lors de la troisième fitna, les deux fils du calife al-Walīd II furent emprisonnés à Damas avant d'être exécutés par les hommes de Sulaymān b. Hishām, commandant les troupes du calife Ibrāhīm (frère de Yazīd III) ${ }^{48}$. Un troisième homme enfermé avec eux, Abū Muhammad al-Sufyān̄i, échappa à la décapitation en s'enfermant dans une cellule et en barricadant la porte à l'aide du matelas (farsh) et des coussins (wasā'id) qui s'y trouvaient ${ }^{49}$. Si le récit est réaliste, le mobilier de cette prison était assez abondant pour sauver le condamné. Une histoire illustrant la piété filiale d'al-Faḍl b. Yahyā suggère que les célèbres vizirs Barmakides, emprisonnés par le calife al-Rashīd, bénéficiaient eux aussi de conditions de détention plus favorables que la moyenne. Ibn Qutayba relate que Yahyā ne faisait ses ablutions qu'avec de l'eau chaude. Une nuit froide, le geôlier refusa d'apporter du bois pour allumer un feu dans leur cellule. Al-Faḍl remplit d'eau une aiguière (qumqum) et la tint au-

\footnotetext{
${ }^{43}$ Al-Ișfahān̄̄, Maqātil al-Ṭālibiȳin : 359.

${ }^{44}$ I. Dick, «La passion arabe de S. Antoine Ruwah », Le Muséon 74 (1961) : 124.

${ }^{45}$ Al-Khașșāf, Adab al-qạ̣̄̄ : 264. Cf. Schneider, «Imprisonment » : 169 ; Rosenthal, The Muslim Concept of Freedom : 68.

${ }^{46}$ Al-Iṣfahānī, Maqātil al-Ṭālibiȳin : 193.

${ }^{47}$ Wakī‘, Akhbār al-quḍ̄t, $3: 171$.

${ }^{48}$ Voir G. Hawting, The First Dynasty of Islam. The Umayyad Caliphate AD 661-750 (Londres-New-York: Routledge, 2000) : 96-97.

${ }^{49}$ Al-Ṭabarī, Ta'rīkh al-rusul wa-l-mulūk, 7 : 302.
} 
dessus d'une lampe (misbāh) jusqu'au matin ${ }^{50}$. De tels détenus privilégiés semblaient non seulement disposer de cellules chauffées, mais également d'éclairage et de vaisselle ordinaire.

Les chaînes (qayd, silsila, hadīd) constituaient le «mobilier » le plus commun des prisons. Les paroles attribuées au calife 'Umar II ${ }^{51}$ légitimaient une pratique visiblement répandue et acceptée : celle d'enchaîner les détenus, ou au moins certains d'entre eux (vauriens et malfaiteurs; les débiteurs, dans les prisons de cadis, n'étaient pas enchaînés). À la fin du $\mathrm{II}^{\mathrm{e}} / \mathrm{VIII}{ }^{\mathrm{e}}$ siècle, le juriste Abū Yūsuf s'en remettait déjà à l'autorité de 'Umar II, tout en atténuant la violence de ses propos. L'accomplissement de la prière étant toujours une obligation pour le détenu musulman, les fers ne devaient pas l'empêcher de prier debout et, de surcroît, les chaînes devaient lui être ôtées pour dormir, à moins qu'il ne soit soupçonné de meurtre (mațlūb bi-dam) ${ }^{52}$. Lues en négatif, ces prescriptions montrent qu'enchaîner les prisonniers était une pratique très répandue, touchant peut-être d'autres catégories que celle des criminels. L'allusion du juriste au fait de «prier debout» suggère qu'il était d'usage d'attacher les détenus au sol (ou au mur, à faible hauteur) à l'aide d'une chaîne trop courte pour leur permettre de se lever - comme cela est nécessaire lors de la prière. Cette interprétation semble confirmée par al-Sarakhsī qui, au $\mathrm{V}^{\mathrm{e}} / \mathrm{XI}^{\mathrm{e}}$ siècle, évoque le cas d'un prisonnier enchaîné qui se voit contraint de prier assis ${ }^{53}$. Incarcéré dans la prison de la 'āmma, à $\operatorname{Bagdad}^{54}$, Aḥmad b. Hanbal parvenait, malgré ses chaînes, à diriger la prière commune avec ses compagnons de cellule, mais insistait aussi pour que les fers n'entravent pas le bon accomplissement de cette obligation rituelle ${ }^{55}$.

Dès l'époque umayyade, les chroniques enregistrent de nombreux exemples de prisonniers enchaînés ${ }^{56}$. Sous les premiers Abbassides, les 'Alīdes et autres détenus politiques étaient particulièrement touchés par cette pratique ${ }^{57}$. Dans le Muṭbaq, les chaînes que certains 'Alīdes portaient aux pieds amaigrissaient et usaient leurs chevilles ${ }^{58}$. Les fers avaient parfois du jeu, comme le raconte 'Alī b. al-Ḥasan b. al-Ḥasan (m. 146/763), emprisonné avec plusieurs de ses compagnons : «Les anneaux de nos chaînes s'étaient élargis et lorsque nous voulions prier ou dormir, nous les ôtions. Et lorsque nous craignions qu'un gardien ne fasse irruption, nous les remettions ${ }^{59}$. » Sous al-Amīn, le poète Abū Nuwās fut enchaîné dans sa

\footnotetext{
${ }^{50}$ Ibn Qutayba, 'Uyūn al-akhbār, $3: 102$.

${ }^{51}$ Voir supra.

${ }^{52}$ Abū Yūsuf, Kitāb al-kharāj : 151 (trad. : 231-32).

${ }^{53}$ Al-Sarakhsī, al-Mabsūt, 1 : 123.

${ }^{54}$ Sur cette prison, voir Tillier, «Prisons et autorités urbaines » 401.

${ }^{55}$ Șāliḥ b. Aḥmad b. Hanbal, Sìrat al-Imām Aḥmad b. Hanbal, éd. Muḥammad al-Zaghlī (Beyrouth : al-Maktab al-islāmī, 1997) : 34.

${ }^{56}$ Voir par exemple al-Ṭabarī, Ta'rīkh al-rusul wa-l-mulūk, $7: 19$.

${ }^{57}$ Voir les cas d'al-Ḥasan b. Mu'āwiya et de son frère Yaz̄̄d dans al-Ișfahān̄̄, Maqātil al-Ṭālibiȳ̄n : 265 ; de Yahyyā b. 'Abd Allāh (leader d'une révolte au Daylam, voir W. Madelung, "Yaḥyā b. 'Abd Allāh », EI ${ }^{2}, 11$ : 242), dans al-Ṭabarī, Ta'rīkh al-rusul wa-l-mulūk, $8: 244$. Sous al-Mutawakkil, voir encore al-Iṣfahān̄̄, Maqātil al-Ṭālibiȳ̄n : 485. Parmi les prisonniers politiques non 'Alīdes, mentionnons Ibn Abī Sabra, percepteur de la șadaqa et futur cadi de Bagdad, qui fut emprisonné en 145/762 pour sa participation à la révolte d'al-Nafs alZakiyya à Médine (al-Ṭabarī, Ta’rīkh al-rusul wa-l-mulūk, 7 : 612).

${ }^{58}$ Voir le cas de 'Abd Allāh b. al-Ḥasan (Cf. K.V. Zetterstéen, «'Abd Allāh b. al-Ḥasan », EI ${ }^{2}, 1$ : 45), en 140/758 (al-Ișfahānī, Maqātil al-Ṭālibiȳ̄n : 193) ; al-Ișfahānī, Maqātil al-Ṭālibiȳ̄n : 405 (sous al-Rashīd).

${ }^{59}$ Al-Ișfahānī, Maqātil al-Ṭālibiȳ̄n : 176-177. Al-Balādhurī, Ansāb al-ashrāf, 4 : 130-131.
} 
prison ${ }^{60}$, tout comme le cadi d'Égypte al- 'Umarī après son arrestation ${ }^{61}$. Sous al-Wāthiq, il en alla de même du comploteur Aḥmad b. Nașr al-Khuzā'̄ et de ses partisans ${ }^{62}$ et, en 269/882, lorsqu'al-Muwaffaq vint à bout des Zanj et ouvrit les portes de leurs prisons, les détenus en sortirent encore serrés dans leurs chaînes et leurs carcans (aghlāl) ${ }^{63}$. En Égypte, les détenus chrétiens d'une certaine importance portaient aux pieds de solides entraves de bois et au cou de lourds colliers de fer ${ }^{64}$. Ces exemples - bien d'autres pourraient s'y ajouter ${ }^{65}$ montrent un usage récurrent des chaînes dans les prisons, restreignant encore la liberté de mouvement dont un détenu aurait autrement profité dans sa cellule. Dans la plupart des cas, on peut douter que la sécurité ait été la principale vocation de ces chaînes : les 'Alīdes qui parvenaient à retirer leurs fers ne s'évadaient pas pour autant, a fortiori lorsqu'ils étaient enfermés dans le Muṭbaq. Les chaînes représentaient plutôt un châtiment supplémentaire, imprimant physiquement la privation de liberté sur le prisonnier. Les termes employés par 'Umar II dans sa lettre sont, peut-être, volontairement ambigus : les «fers » (nakāl) dont le calife menace les vauriens peuvent aussi bien faire allusion à un «supplice », et l'idée d'un enchaînement douloureux (au physique comme au moral) doit certainement être retenue. Destinée à faire souffrir «à la hauteur de la gravité de l'acte commis ${ }^{66}$ », l'incarcération serait ainsi entrée dans une logique d'expiation.

Les chaînes apparaissaient comme le principal symbole de l'emprisonnement. Al-Jāḥiz comme Ibn Qutayba proposent de courtes anthologies de poèmes composés par des détenus où les chaînes et le carcan - ghull, probablement un collier de fer (zammāra) - apparaissent comme les principaux leitmotivs ${ }^{67}$. Dans la même section, Ibn Qutayba relate l'histoire d'un homme arbitrairement emprisonné par le cadi bașrien Bilāl b. Abī Burda ${ }^{68}$. Comme il lui demandait la raison de son incarcération, le cadi s'exclama : «Une porte massive, de lourdes chaînes et un geôlier appelé Ḥafs se chargeront de t'en informer ${ }^{69}$ ! Cette réponse cinglante brossait à grands traits les caractéristiques de la prison dans l'imaginaire de l'époque : le plus difficile à endurer n'était pas l'étroitesse de la cellule - comme dans les zinzāna-s de la littérature syrienne contemporaine -, mais le poids des chaînes.

\footnotetext{
${ }^{60}$ Al-Ṭabarī, Ta'rīkh al-rusul wa-l-mulūk, $8: 515$.

${ }^{61}$ Al-Kind̄̄, Akhbār quḍāt Mișr : 412.

${ }^{62}$ Al-Ṭabarī, Ta'rīkh al-rusul wa-l-mulūk, 9 : 137.

${ }^{63}$ Al-Ṭabarī, Ta'rīkh al-rusul wa-l-mulūk, $9: 641$.

${ }^{64}$ Severus ben el-Moqaffa', Historia Patriarcharum Alexandrinorum, 1: 152, 181, 201, 202, 203, 217, 223,225 , 227, 234, 238.

${ }^{65}$ Voir par exemple C.E. Bosworth, The Medieval Islamic Underworld (Leyde : Brill, 1976), 1 : 43-44. Sur l'enchaînement de détenus chrétiens, voir également I. Dick, « La passion arabe » : 125.

${ }^{66} \mathrm{Ph}$. Combessie, Sociologie de la prison (Paris : La Découverte, 2004) : 15.

${ }^{67}$ Al-Jāḥiz, al-Bayān wa-l-tabyīn, 3 : 64 ; Ibn Qutayba, 'Uyūn al-akhbār, 1 : 120-121.

${ }^{68}$ Sur ce cadi, voir M. Tillier, «Les prisonniers dans la société musulmane », dans E. Malamut et Ch. Raynaud (éd.), Vivre en société au Moyen Âge (Aix-en-Provence : Presses Universitaires de Provence, à paraître).

${ }^{69}$ Ibn Qutayba, 'Uyūn al-akhbār, $1: 120$.
} 


\section{Se nourrir, s'habiller et se laver en prison}

\subsection{La nourriture}

Selon al-Șābi', le budget mensuel alloué à l'entretien des détenus en nourriture, en eau et en autres fournitures s'élevait à 1550 dinars sous le calife al-Mu' taḍid (r. 279/892-289/902) ${ }^{70}$. Comme le nombre de prisonniers concernés est inconnu, les implications d'un tel budget sont impossibles à évaluer. Il semble néanmoins que les prisons n'avaient pas pour vocation d'entretenir les détenus au-delà du minimum vital. La nourriture distribuée semblait essentiellement constituée de pain et d'eau. Selon al-Iṣfahānī, le 'Alīde Yaḥyā b. 'Abd Allāh, enfermé dans le Muṭbaq sous al-Rashīd, recevait quatre pains (raghïf) par jour et huit ratl-s d'eau. Sa ration quotidienne fut d'abord réduite de moitié, puis encore de moitié. Affaibli, l'homme tomba malade et mourut ${ }^{71}$. Les détenus devaient eux-mêmes compléter de telles rations de base en fonction de leurs moyens. Se demandant s'il est normal que des prisonniers meurent de faim, Abū Yūsuf préconise le versement d'une pension aux détenus désargentés. Son insistance sur une dotation en numéraire - et non en nature car le pain distribué risquerait d'être détourné par les gardiens - montre qu'il revenait à chaque détenu d'acheter lui-même sa nourriture ${ }^{72}$.

Les détenus les plus fortunés se faisaient apporter à manger de l'extérieur. Lors de son incarcération à Harrān, l'Imam Ibrāhīm ${ }^{73}$ envoyait son affranchi Muhalhil lui acheter tout ce dont il avait besoin, notamment de la nourriture ${ }^{74}$. Beaucoup de prisonniers comptaient sur le soutien matériel de leurs proches. À l'époque umayyade, un compagnon de détention du savant médinois Sa $1 \overline{1}$ d b. al-Musayyab (m. 94/713) se faisait envoyer de la nourriture par sa famille $^{75}$. Shurayh, un des premiers cadis de Kūfa, dut emprisonner son propre fils après la fuite d'un homme dont il s'était porté garant ; à titre privé, il lui fit néanmoins porter à manger dans sa geôle ${ }^{76}$. Sous al-Mutawakkil, alors qu'un prisonnier 'alīde s'était vu interdire tout droit de visite, une femme parvint à corrompre le geôlier : elle lui apporta ainsi de l'argent, des vêtements et du parfum, et obtint qu'un intermédiaire lui fasse parvenir chaque jour de la «nourriture propre » (ta ${ }^{`} \bar{a} m$ naẓîf $){ }^{77}$.

Ceux qui ne pouvaient compter sur leurs proches bénéficiaient parfois de la générosité de compagnons de cellule plus chanceux, tel ce jeune prisonnier 'alīde avec qui Ya 'qūb b. Dā'ūd partagea sa nourriture et sa boisson dans le Muṭbaq ${ }^{78}$. Ils dépendaient cependant surtout de

\footnotetext{
70 Al-Ṣābi', al-Wuzarā', éd. 'Abd al-Sattār Aḥmad Farāj (s.l. : Dār iḥyā' al-kutub al- arabiyya, 1958) : 21. Le texte édité mentionne «awqāt» probablement en lieu de «aqwāt». Sur la théorie juridique relative au financement des prisons et à l'entretien des prisonniers, voir Abū Ghudda, Aḥkām al-sijn : 237 sq.

${ }^{71}$ Al-Iṣfahānī, Maqātil al-Ṭālibiȳ̄n : 402.

${ }^{72}$ Abū Yūsuf, Kitāb al-kharāj : 151 (trad. : 232).

${ }^{73}$ Sur ce personnage, voir supra.

${ }^{74}$ Al-Balādhurī, Ansāb al-ashrāf, $4: 165$.

${ }^{2}$ Al-Fasawī, al-Ma 'rifa wa-l-ta'rīkh, éd. Akram Ḍiyā' al- 'Umarī (Médine : Maktabat al-dār bi-l-Madīna 1munawwara, 1410 H.), 1 : 474. Sur Sa'īd b. al-Musayyab, voir al-Ziriklī, al-A 'lām, 3 : 102.

${ }^{76}$ Ibn Sa d, al-Ṭabaqāt al-kubrā, 4 : 134 ; Wakī`, Akhbār al-quḍāt, 2 : 317.

77 Al-Iṣfahānī, Maqātil al-Tâalibiȳ̄n: 485. Dans l'Égypte de la fin de l'époque umayyade, des prisonniers chrétiens semblaient compter, pour manger, sur ce que leur envoyait un certain Ibn Kastas. Severus ben elMoqaffa', Historia Patriarcharum Alexandrinorum, 1: 201.

${ }^{78}$ Al-Ṭabarī, Ta'rīkh al-rusul wa-l-mulūk, $7: 607$.
} 
l'État et de l'aumône publique ${ }^{79}$. Abū Yūsuf préconise l'entretien des détenus nécessiteux par le Trésor public, qui devrait leur verser une pension mensuelle de 10 dirhams ${ }^{80}$. La simple présence de cette recommandation dans le Kitāb al-kharāj laisse penser que l'État jouait en réalité un rôle secondaire - en tout cas inférieur aux souhaits d'Abū Yūsuf. Le versement d'allocations aux détenus pauvres était un événement assez rare pour mériter mention dans les chroniques. Ainsi al-Ṭabarī observe-t-il qu'en 162/778-79, le calife al-Mahdī «ordonna d'attribuer dans tout l'empire [des pensions ?] aux lépreux et aux détenus (ahl al-sujūn) » ${ }^{81}$. Le rôle de la charité publique - également sous-entendu par Abū Yūsuf - était sans doute beaucoup plus important. À la fin du II $/ \mathrm{VIII}^{\mathrm{e}}$ siècle, chez les Coptes d'Égypte, les aumônes versées aux orphelins, aux veuves et aux prisonniers étaient placées sur le même plan ${ }^{82}$. Au $\mathrm{III}^{\mathrm{e}} / \mathrm{IX}^{\mathrm{e}}$ siècle, al-Jāhiz évoque une sorte de pain, le zakūrī, qu'il définit comme le «pain de l'aumône que l'on donne aux prisonniers ou aux mendiants ${ }^{83}$ ». À la différence de l'entretien direct par le pouvoir, la distribution d'aumônes aux détenus était assez courante pour que son interruption ou son absence soit mentionnée dans les chroniques. En 231/845-46, le comploteur Aḥmad b. Naṣr al-Khuzā '̄i fut exécuté par le calife al-Wāthiq ; ses partisans furent arrêtés, jetés dans d'obscurs cachots et «privés de l'aumône (șadaqa) que l'on distribue aux détenus ${ }^{84}$. Cette mesure punitive, due à la gravité de leur crime, montre a contrario que la plupart des détenus vivaient de la charité publique ${ }^{85}$.

Peut-être les prisonniers durent-ils, à certaines époques, aller eux-mêmes demander l'aumône à l'extérieur de leurs prisons. Abū Yūsuf adresse en effet le conseil suivant au calife al-Rashīd : «Dispense-les de la nécessité de sortir enchaînés et de recevoir l'aumône, car c'est une chose grave que de voir des musulmans qui sont en faute et qui sont détenus par suite de ce qu'Allâh a décrété à leur sujet, sortir enchaînés et recevoir l'aumône ! [...] Ils ne le font que poussés par la faim et ils peuvent être secourus comme aussi ne pas l'être. »Un manuscrit ajoute qu'alors «ils sont exploités et pressurés par les portiers et gardiens, qui se font remettre la totalité ou la plus grande partie de ce qu'ils ont recueilli en nature ou en argent ${ }^{86} »$. Cette prescription laisse entendre qu'à la fin du II $^{\mathrm{e}} / \mathrm{VIII}{ }^{\mathrm{e}}$ siècle, des prisonniers étaient effectivement «sortis » par leurs geôliers, enchaînés, et promenés dans les rues pour y mendier leur subsistance - le produit de leur quête étant largement rançonné par les gardiens ${ }^{87}$. Une telle pratique témoignerait de l'insuffisance de l'aumône institutionnelle reversée aux détenus, placés en définitive dans une situation de très forte dépendance vis-à-vis

\footnotetext{
${ }^{79}$ Cf. Rosenthal, The Muslim Concept of Freedom : 61.

${ }^{80}$ Abū Yūsuf, Kitāb al-kharāj : 151 (trad. : 231). Cf. les recommandations plus tardives d'al-Māwardī, Nasīhat al-mulūk, éd. Kh.M. Khiḍr (al-Ṣafāt : Maktabat al-falāḥ, 1983) : 202. Voir A. Mez, The Renaissance of Islam (Patna : Jubilee, 1937) : 375.

${ }^{81}$ Al-Ṭabarī, Ta'rīkh al-rusul wa-l-mulūk, 8 : 142. Cf. Abū Ghudda, Ahkām al-sijn : 239.

${ }^{82}$ Severus ben el-Moqaffa', Historia Patriarcharum Alexandrinorum, 1: 232.

${ }^{83}$ Al-Jāḥiz, al-Bukhalā', éd. A. al- 'Awāmirī (Beyrouth : Dār al-kutub al- ilmiyya, 1988), 1 : 100.

${ }^{84}$ Al-Ṭabarī, Ta'rīkh al-rusul wa-l-mulūk, 9 : 139.

${ }^{85}$ D'autres formes de charité se développèrent par la suite. À l'époque mamelouke, les revenus de certains waqfs du Caire étaient ainsi affectés à l'entretien des prisonniers. A. Sabra, Poverty and Charity in Medieval Islam. Mamluk Egypt, 1250-1517 (Cambridge : Cambridge University Press, 2000) : 86.

${ }^{86}$ Abū Yūsuf, Kitāb al-kharāj : 152 (trad. : 232).

${ }^{87}$ Sur une pratique comparable à l'époque seldjoukide, voir Lange, Justice : 92. Pour la période mamelouke, voir Sabra, Poverty and Charity : 67 ; Martel-Thoumian, « De l'équité à l'arbitraire » : 230.
} 
de l'extérieur: soit leurs proches pouvaient les entretenir, soit ils en étaient réduits à une forme de mendicité organisée. Le parallèle entre le prisonnier et le mendiant, établi par alJāhị à propos du zakūrī, n'était peut-être pas fortuit. De fait, la faim apparaît, au même titre que les chaînes, comme un des lieux communs les plus récurrents à propos de la prison ${ }^{88}$. Au début $\mathrm{du} \mathrm{IV}^{\mathrm{e}} / \mathrm{X}^{\mathrm{e}}$ siècle, les détenus de Nāṣir al-Dawla souffraient tant de leurs conditions de détention - et notamment de la faim - que l'émir hamdānide finit par examiner individuellement leurs cas, en libérant beaucoup, coupant quelques têtes et quelques mains, et finissant par vider totalement ses prisons ${ }^{89}$.

\subsection{Le vêtement}

Les recommandations attribuées à 'Umar II suggèrent que le pouvoir prit assez tôt des mesures pour vêtir les détenus. En dehors de ces déclarations, seul Abū Yūsuf évoque ce sujet, mais encore s'agit-il de conseils au calife al-Rashīd et nulle source ne confirme que ses recommandations furent appliquées. Selon lui, l'État doit prendre en charge l'habillement des détenus, leur fournissant en hiver une longue chemise (qamīs) ${ }^{90}$ et un manteau (?) (kisā') et, en été, une longue chemise et un châle/vêtement d'extérieur $(i z \bar{a} r)^{91}$. Les femmes devaient recevoir un voile de tête (miqna 'a) ${ }^{92}$ en plus de ces vêtements. Un des manuscrits du Kitāb al-kharāj ajoute que «le manteau leur sera retiré lors de leur libération et sera employé pour d'autres prisonniers ${ }^{93}$. Une intendance chargée de distribuer et de recycler des vêtements «carcéraux » semblait donc exister dans les prisons, au moins sur le plan théorique. Il est néanmoins probable que nombre de prisonniers se vêtaient grâce aux aumônes publiques ${ }^{94}$.

\subsection{L'hygiène du corps et de l'âme}

Les fuqahā' considéraient les cinq prières quotidiennes comme obligatoires même si les chaînes empêchaient le détenu d'effectuer les rak' $a$-s ordinaires : selon al-Sarakhsī, Abū Yūsuf recommandait en ce cas de remplacer les inclinations par des signes de tête $(\bar{\imath} m \bar{a})^{\prime}{ }^{95}$. L'obligation de la prière collective était plus controversée. D'après Ibn Abī Shayba (m. 235/849), les Bașriens et les Kūfiotes du $\mathrm{II}^{\mathrm{e}} / \mathrm{VIII}{ }^{\mathrm{e}}$ siècle étaient en désaccord à ce sujet : à Bașra, comme dans la doctrine des Médinois ${ }^{96}$, Ibn Sīrīn ${ }^{97}$ réclamait que les détenus soient regroupés le vendredi pour effectuer ensemble la prière, tandis qu'à Kūfa la tradition placée

\footnotetext{
${ }^{88}$ Voir notamment al-Kindī, Akhbār quḍāt Miṣr : 456.

${ }^{89}$ Al-Șūlī, Akhbār al-Rāọ̄ wa-l-Muttaqū, éd. J. Heyworth Dunne (Le Caire : al-Șāwī, 1935) : 232. Sur la faim dans les prisons fāțimides, voir D. Cortese et S. Calderini, Women and the Fatimids in the World of Islam (Edinburgh : Edinburgh University Press, 2006) : 215.

${ }^{90}$ Voir R. Dozy, Dictionnaire détaillé des noms de vêtements chez les Arabes (Amsterdam : Jean Müller, 1843) : 371-72.

${ }^{91}$ Dozy interprète le izār comme un manteau (Dozy, Dictionnaire détaillé : 24). Fagnan préfère traduire le terme par « caleçon » (Fagnan, in Abou Yousof Ya'koub, Le Livre de l'impôt foncier : 232).

${ }^{92}$ Voir Dozy, Dictionnaire détaillé : 375.

${ }^{93}$ Abū Yūsuf, Kitāb al-kharāj : 152 (cf. trad. : 232).

${ }^{94}$ Voir Severus ben el-Moqaffa ', Historia Patriarcharum Alexandrinorum, 1 : 232.

${ }^{95}$ Al-Sarakhsī, al-Mabsūt, 1 : 123.

${ }^{96}$ Saḥnūn, al-Mudawwana l-kubrā (Beyrouth : Dār Șādir, s.d.), 1 : 159.

${ }^{97}$ Sur ce Successeur (m. 110/728), voir T. Fahd, « Ibn Sīrīn », EI², 3 : 947.
} 
sous le nom d'Ibrāhīm al-Nakha'ī ${ }^{98}$ affirmait «que les prisonniers n'ont pas de prière collective $»{ }^{99}$. Rien n'indique que les prisons possédaient à cette époque une mosquée ou une salle de prière, ni même un imam attitré ${ }^{100}$. Une anecdote relatée par al-Jāhị est de ce point de vue significative. Irrité par le semi-légendaire Ash 'ab ${ }^{101}$, invité à sa table, un gouverneur umayyade de Kūfa demanda : «Les prisonniers ont-ils un imam qui préside à leur prière ? »«Non », répondit-on. - «Ash`ab dirigera donc leur prière. » ${ }^{102}$ Cette menace d'emprisonnement révèle l'absence de tout imam institutionnel : un détenu plus instruit que ses compagnons pouvait lui-même, à sa convenance, organiser et diriger la prière collective. La prison n'était pas conçue pour sauver les âmes et, même si une logique d'amendement peut parfois être décelée ${ }^{103}$, l'institution carcérale n'organisait pas la vie spirituelle des détenus.

La question de la prière était étroitement liée à celle des ablutions. Les détenus semblaient souvent manquer d'eau. Sur le plan juridique, al-Sarakhsī s'interroge au $\mathrm{V}^{\mathrm{e}} / \mathrm{XI}^{\mathrm{e}}$ siècle sur la validité de la prière en prison s'il n'y a pas d'eau pour effectuer au préalable les ablutions canoniques. Évoquant la saleté à laquelle un détenu peut être confronté ${ }^{104}$, il remarque que «l'absence d'eau en prison n'est pas quelque chose de rare »; s'il en manque, le prisonnier peut se contenter du tayammum, mais il doit en principe renouveler sa prière lorsqu'il obtient une quantité d'eau suffisante ${ }^{105}$. Dans sa prison de Bagdad, Aḥmad b. Hanbal n'avait pas assez d'eau et un certain Būrān lui en apportait dans une cruche (dawraq) depuis l'extérieur ${ }^{106}$. Dans la Fusțāt de la fin du III $/ \mathrm{IX}^{\mathrm{e}}$ siècle, le cadi Bakkār b. Qutayba, emprisonné par Ibn Ṭūlūn, parvenait néanmoins à se laver chaque vendredi, dans l'espoir que l'émir lui accorderait une permission de sortie pour se rendre à la grande mosquée ${ }^{107}$.

\section{Tomber malade et mourir en prison}

De telles conditions matérielles ne favorisaient guère la bonne santé des détenus. Ibn Taghrī Birdī décrit ainsi la situation extrême à laquelle des 'Alīdes furent réduits sous alManșūr :

Al-Haytham dit :

\footnotetext{
${ }^{98}$ Sur ce personnage, voir J. Schacht, The Origns of Muhammadan Jurisprudence (Oxford : Clarendon Press, 1950) : 33 et passim.

${ }^{99}$ Ibn Abī Shayba, al-Mușannaf, éd. Kamāl Yūsuf al-Ḥūt (Riyad : Maktabat al-rushd, 1409 H.), $1: 484$.

${ }^{100}$ Cf. Rosenthal, The Muslim Concept of Freedom : 63.

${ }^{101}$ Sur Ash 'ab b. Jubayr, dit al-Țāmi` (m. 154/771 ?), voir F. Rosenthal, « Ash' ab », EI $I^{2}, 1: 690$; al-Ziriklī, alA '⿳亠े冖m, $1: 332$.

${ }^{102}$ Al-Jāhị, al-Bukhalä', 2: 84 ; trad. Ch. Pellat dans Le Livre des avares (Paris: Maisonneuve et Larose, 1997) : 216 .

${ }^{103}$ Cette logique d'amendement était particulièrement évidente lorsqu'un criminel était incarcéré jusqu'à ce qu'il se repente. Voir Tillier, «Les prisonniers dans la société musulmane », à paraître.

${ }^{104} \mathrm{Cf}$. Cortese et Caldernini, Women and the Fatimids : 215.

${ }^{105}$ Al-Sarakhsī, al-Mabsūt, $1: 123$. Sur le manque d'eau en prison voir C.F. Petry, «Al-Maqrīzī’s Discussion of Imprisonment and Description of Jails in the Khițat », Mamluk Studies Review 7 (2003) : 140.

${ }^{106}$ Șāliḥ b. Aḥmad b. Hanbal, Sìrat al-Imām Ahmad b. Hanbal : 34.

${ }^{107}$ Ibn Ḥajar, Raf' al-iṣr 'an quḍāt Miṣr, éd. 'Alī Muḥammad 'Umar (Le Caire : Maktabat al-Khānjī, 1998) : 107 ; trad. M. Tillier, Vies des cadis de Mișr (Le Caire : Ifao, 2002) : 70.
} 
Abū Ja far al-Manșūr les emprisonna dans une cave (sirdāb), sous la terre, où ils ne pouvaient distinguer la nuit du jour. Cette cave se trouvait près du pont de Kūfa ${ }^{108}$, maintenant lieu de pèlerinage (mawdi ' yuzār). Ils n'avaient pas de puits ni de citerne pour s'approvisionner en eau ; ils urinaient et déféquaient sur place. Lorsque l'un d'entre eux mourait, ils ne l'enterraient pas et il se putréfiait sous leurs yeux. L'odeur d'urine et d'excréments était insupportable. Leurs pieds commençaient par gonfler, puis la tuméfaction gagnait leurs cœurs et ils mouraient. On raconte qu'Abū Ja'far al-Manșūr fit remblayer la cave sur eux et qu'ils moururent : on entendit encore leurs plaintes pendant plusieurs jours ${ }^{109}$.

Même si les prisons étaient d'ordinaire moins malsaines, le manque de confort et de nourriture risquait de fragiliser les détenus. Le savant bașrien Wahīb b. Khālid (m. $165 / 781){ }^{110}$ perdit ainsi la vue en prison ${ }^{111}$. Or nulle structure n'était prévue pour accueillir les détenus malades. Les prisons manquaient de personnel de soin et l'on n'entend pas parler de visites quotidiennes de médecins avant le $\mathrm{IV} / \mathrm{X}^{\mathrm{e}}$ siècle ${ }^{112}$. Au siècle précédent, al-Khașṣāf préconisait, en cas d'incarcération pour dette, qu'un détenu malade soit libéré si personne dans sa famille ne pouvait venir s'occuper de lui ${ }^{113}$.

Il n'était pas rare de mourir de maladie en prison, comme l'atteste la tenue par l'administration carcérale de listes de prisonniers décédés ${ }^{114}$. Bilāl b. Abī Burda, cadi et gouverneur de Bașra à l'époque umayyade, finit emprisonné par son successeur, Yūsuf b. 'Umar. Il redoutait tant d'être assassiné dans sa prison qu'il paya le geôlier pour inscrire son nom sur la liste des détenus décédés : il espérait être ainsi oublié par ses ennemis. Le gouverneur apprit néanmoins l'affaire et le fit effectivement assassiner ${ }^{115}$. Selon une autre version, Yūsuf b. 'Umar aurait demandé à voir le cadavre de Bilāl et le geôlier, de crainte d'être pris en flagrant délit de corruption, aurait étranglé Bilāl ${ }^{116}$. Les sources tiennent les autorités carcérales pour dangereuses : les chroniques abondent en exemples de détenus surtout politiques - que les autorités auraient empoisonnés ou laissé mourir de faim. Au-delà de sa dimension religieuse - particulièrement importante pour les 'Alīdes, accédant ainsi martyre -, un tel topos reflète la réelle vulnérabilité des détenus vis-à-vis de leurs geôliers et, plus généralement, de leurs conditions de détention.

Les juristes s'interrogent pour leur part sur la responsabilité des autorités en cas de décès d'un détenu. Si un prisonnier est privé de nourriture et/ou de boisson, et s'il meurt tout de suite après, al-Shāfi ${ }^{\prime} \overline{1}$ (m. 204/820) ne tient pas le pouvoir (al-sulțān) pour responsable tant que celui-ci n'avoue pas que l'homme est mort par sa faute. En revanche, si les privations se

\footnotetext{
${ }^{108}$ Qanțarat al-Kūfa : ce pont de pierre, restauré par 'Umar b. Hubayra, permettait de traverser l'Euphrate au niveau de Kūfa. Al-Balādhurī, Futūḥ al-buldān, éd. Riḍwān Muḥammad Rị̣wān (Beyrouth : Dār al-kutub al'ilmiyya, 1403 H.) : 285.

${ }^{109}$ Ibn Taghrī Birdī, al-Nujūm al-zāhira (Le Caire : Wizārat al-thaqāfa wa'l-irshād al-qawmī, 1930), $2: 4$.

${ }^{110}$ Al-Ziriklī, al-A 'ām, $8: 126$.

${ }^{111}$ Ibn Sa'd, al-Tabaqāt al-kubrāa $7: 287$.

${ }^{112} \mathrm{Mez}$, The Renaissance of Islam : 375.

${ }^{113}$ Al-Khașșāf, Adab al-qạ̄̂̀ : 264. Cf. al-Simnānī, Rawḍtat al-quḍāt, $1: 132$.

${ }^{114}$ Selon al-Simnānī (Rawḍtat al-quḍāt, $1: 132$ ), le geôlier du cadi devait lui transmettre un rapport quotidien sur les affaires des prisonniers.

${ }^{115}$ Al-Jāhịiz, al-Bayān wa'l-tabyīn, 2 : 166.

${ }^{116}$ Al-Balādhurī, Ansāb al-ashrāf, 9 : 111 ; cf. Ibn Khallikān, Wafayāt al-a yān, éd. Iḥsān 'Abbās (Beyrouth : Dār Șādir, 1994), 7 : 106.
} 
prolongent assez longtemps pour avoir pu provoquer le décès, et si la famille du prisonnier porte plainte, le pouvoir est considéré comme responsable et doit le prix du sang (diya). Il en va de même si un détenu meurt faute d'avoir été vêtu ou chauffé à suffisance : en cas de froid modéré, le pouvoir est disculpé car le prisonnier a pu mourir de maladie. Mais s'il est véritablement mort de froid, le pouvoir est tenu pour responsable ${ }^{117}$. Au v $/ \mathrm{XI}^{\mathrm{e}}$ siècle, la dangerosité de la détention collective pousse également le ḥanafite al-Sarakhsī à réfléchir au versement de la diya si un prisonnier est retrouvé assassiné. Selon la doctrine attribuée à Abū Yūsuf, elle doit être payée par ses codétenus, par analogie entre la prison et un quartier où la responsabilité est collective. Cette opinion offre l'image de structures carcérales minimalistes, au sein desquelles il revient finalement aux détenus d'organiser eux-mêmes leur vie sociale. La doctrine attribuée à Abū Ḥanīfa (m. 150/767) et al-Shaybānī (m. 189/805) ôte en revanche aux codétenus toute responsabilité, considérant qu'ils se trouvent dans une situation d'assujettissement (maqhūrīn) ne leur laissant qu'une capacité limitée à s'autogérer ; comme par ailleurs l'incarcération est prononcée pour le bien (manfa 'a) des musulmans, il revient au Trésor public (et donc à l'État) de payer la diya ${ }^{118}$.

La prière sur le défunt, juste avant l'inhumation, apparaissait comme un rite essentiel de l'islam, en général réalisé par un proche parent ${ }^{119}$. Mais les prisonniers les plus connus incarcérés pour des raisons politiques - étaient souvent détenus loin de leurs familles, ou leurs plus proches parents croupissaient eux aussi en prison. On vit ainsi, vers 144/761, un geôlier autoriser un Hasanide médinois à sortir temporairement de prison pour aller prier sur la dépouille de son frère, mort en détention à al-Hāshimiyya ${ }^{120}$. Les obsèques de certains détenus devaient être assez sommaires. Ibn Qutayba relate que Harthama b. A yan, général d'al-Ma'mūn, mourut emprisonné à Marw. Son corps fut enveloppé dans une étoffe grossière et enterré «dans une tranchée (khandaq) [réservée] aux prisonniers de Marw ${ }^{121}$ »visiblement une fosse commune. Dans son Kitāb al-kharāj, Abū Yūsuf déplore le manque de soin porté aux dépouilles mortelles des prisonniers : «Je sais et je tiens d'hommes dignes de foi qu'il arrive souvent que le cadavre d'un détenu étranger reste un et deux jours dans la prison avant que le directeur soit consulté et qu'alors les détenus survivants réunissent, à l'aide d'aumônes faites de leurs deniers, de quoi louer un homme pour le porter au cimetière, où il est inhumé sans avoir été lavé ni enveloppé dans un linceul (kafan) ni accompagné des dernières prières; fait bien grave dans l'Islam et pour ceux qui le professent! » Pour le célèbre juriste, le Trésor public devait donc prendre en charge les funérailles (toilette mortuaire et inhumation) des prisonniers sans famille ${ }^{122}$. Des obsèques non réglementaires apparaissaient comme la pire forme d'exclusion de la Communauté musulmane ${ }^{123}$ : dans les faits, l'exclusion du prisonnier se poursuivait bien souvent au-delà de sa mort.

\footnotetext{
${ }^{117}$ Al-Shāfi ‘̂̀, al-Umm, éd. Muḥammad Zuhrī al-Najjār (Beyrouth : Dār al-ma rifa, 1973), $6: 88$.

${ }^{118}$ Al-Sarakhsī, al-Mabsūt, $26: 112-113$.

${ }^{119}$ A.S. Tritton, «Djanāza », $E I^{2}, 2: 441$.

${ }^{120}$ Al-Ṭabarī, Ta'rīkh al-rusul wa'l-mulūk, 7 : 551.

${ }^{121}$ Ibn Qutayba, al-Ma 'ârif, éd. Tharwat 'Ukāsha (Le Caire : Dār al-ma'ārif, s.d.) : 389. Sur Harthama b. A'yan (m. 200/816), voir Ch. Pellat, « Harthama b. A'yan », $E I^{2}, 3: 231$.

${ }^{122}$ Abū Yūsuf, Kitāb al-kharāj : 152 (trad. : 233 [traduction adaptée]).

${ }^{123}$ M.Q. Zaman, «Death, Funeral Processions, and the Articulation of Religious Authority in Early Islam», Studia Islamica 93 (2001) : 30-31.
} 


\section{Conclusion}

Promiscuité, saleté, faim, maladie : tel semblent avoir été les traits communs de la vie des prisonniers aux $\mathrm{III}^{\mathrm{e}} / \mathrm{IX}^{\mathrm{e}}$ et $\mathrm{IV}^{\mathrm{e}} / \mathrm{X}^{\mathrm{e}}$ siècles. De ce point de vue, il n'est pas certain que les conditions de vie aient été meilleures dans les «prisons de cadis» que dans les «prisons des voleurs » : selon al-Khașșāf et al-Jașșāṣ, ces deux types de prisons différaient surtout par leur degré de dangerosité, intrinsèquement lié aux populations qu'elles accueillaient majoritairement - débiteurs pour les unes, malfaiteurs pour les autres ${ }^{124}$. Les conditions de vie variaient avant tout selon le niveau socioéconomique des détenus ${ }^{125}$. Certains prisonniers politiques semblaient privilégiés, surtout si leur détention entendait les neutraliser de manière préventive. Lorsqu'en 187/803 al-Rashīd emprisonna l'Abbasside 'Abd al-Malik b. Șāliḥ, général sur lequel se portaient de vagues soupçons, il le traita bien et lui fit dire que tout ce dont il ressentirait le besoin lui serait apporté ${ }^{126}$. Un riche prisonnier pouvait de surcroît améliorer son confort quotidien en introduisant dans sa cellule ce que l'administration carcérale ne lui fournissait pas - y compris des esclaves, dans certains cas ${ }^{127}$. Dans les prisons pour malfaiteurs, ou en cas de $t a$ 'zìr prononcé par le cadi, la précarité matérielle des détenus participait d'une logique punitive - et non d'une simple neutralisation -, au point que l'eschatologie musulmane érigea l'emprisonnement en châtiment possible dans l'au-delà ${ }^{128}$. La précarité jouait aussi un rôle essentiel dans les «prisons de cadis » qui, bien souvent, visaient plus à faire pression sur le détenu qu'à le sanctionner ${ }^{129}$ : un débiteur qui refusait d'acquitter ses dettes en prétextant son insolvabilité se voyait obligé de sortir son bas de laine, soit pour acheter ce qui lui manquait en prison - auquel cas il exposait au grand jour ses capacités économiques réelles ${ }^{130}$-, soit pour rembourser son créancier et obtenir ainsi sa libération. La pression exercée sur le débiteur était atteinte tant par la privation de liberté que par la précarité matérielle de l'institution carcérale.

La dangerosité de certaines prisons oblige à s'interroger sur le statut juridique du détenu. Dans une des rares réflexions classiques sur le sujet, al-Shāfi'ī laisse entendre que le prisonnier musulman ne pouvait pas témoigner devant un cadi s'il n'était pas reconnu comme honorable avant sa mise en détention. Or les «prisons des voleurs » ne devaient pas souvent accueillir d'hommes respectables et considérés comme ' $a d l$. Si un détenu perpétrait un crime à l'encontre d'un autre (vol, meurtre, etc.) sous les yeux de ses codétenus, sa culpabilité ne pouvait donc pas être établie ${ }^{131}$. De ce point de vue, les prisons apparaissaient comme des espaces de non-droit, et celles des «voleurs» étaient d'autant plus périlleuses qu'elles

\footnotetext{
${ }^{124}$ Al-Khașșāf et al-Jașșāṣ, Adab al-qā

${ }^{125}$ Sur la hiérarchie des sanctions en fonction des catégories sociales, voir Schneider, «Imprisonment » : 163164.

${ }^{126}$ Al-Ṭabarī, Ta'rīkh al-rusul wal-l-mulük, $8: 305$.

${ }^{127}$ Voir Tillier, «Les prisonniers », à paraître.

${ }^{128}$ Lange, Justice : 133-37.

${ }^{129}$ Voir G. Libson, Jewish and Islamic Law. A Comparative Study of Custom During the Geonic Period (Cambridge : Harvard University Press, 2003), 128.

${ }^{130}$ Al-Khașșāf (Adab al-qāḍ̂ : 270) s'inquiète même des dépenses excessives qu'un débiteur pourrait engager en prison, risquant par-là même de le ruiner, et demande au cadi de lui fournir dans ce cas ce dont il a besoin (dans la limite du raisonnable).

${ }^{131}$ Al-Shāfi ‘̄i al-Umm, $6: 142 ; 7: 32$.
} 
réunissaient des criminels susceptibles de poursuivre leurs activités derrière les barreaux sans risque majeur de sanction.

Les conditions d'emprisonnement poussèrent-elles les détenus à la mutinerie ? Plusieurs révoltes sont rapportées dans les chroniques. Après avoir repris le contrôle de Bagdad à son retour du Khurāsān, al-Ma'mūn envoya plusieurs agitateurs et opposants en prison. Mais en 210/825-26, ceux-ci prirent la tête d'une mutinerie (shaghab) dans le Muṭbaq : les portes en furent barricadées de l'intérieur, empêchant quiconque d'y entrer, et les détenus menacèrent de démolir les murs ${ }^{132}$. Selon al-Ya qūbī, certains mutins se seraient même faits chrétiens, se ceignant du zunnār et suspendant une croix à leurs cous. Prévenu par le șāhị al-barīd, alMa'mūn ramena le calme en faisant exécuter et crucifier sur un pont de Bagdad les principaux chefs de la révolte ${ }^{133}$. En 306/918, les détenus de la Prison nouvelle ${ }^{134}$ se mutinèrent et en escaladèrent le mur d'enceinte. Nizār b. Muhammad, le Préfet de police, envoya contre eux des cavaliers : les prisonniers revinrent à la raison après qu'il eut lancé la tête de l'un d'entre eux, qu'il avait tué de ses propres mains, par-dessus les murailles ${ }^{135}$. Peut-être de telles révoltes furent-elles favorisées par l'âpreté des conditions générales de détention.

\section{BIBLIOGRAPHIE}

Abou Yousof Ya'koub. 1921. Le Livre de l'impôt foncier. Paris : Paul Geuthner.

Abū Ghudda, H. 'A.-Gh. 1986. Ahkām al-sijn wa-mu 'āmalat al-sujanā' fì l-islām, Thèse de doctorat. Tunis : Université de la Zītūna.

Abū Yūsuf. 1984. Kitāb al-kharāj, éd. Maḥmūd al-Bājī. Tunis : Dār Bū Salāma.

al-Balādhurī. 1996. Ansāb al-ashrāf, éd. Suhayl Zakkār et Riyāẹ Ziriklī. Beyrouth : Dār al-fikr.

-. 1403 H. Futūḥ al-buldān, éd. Rị̣wān Muḥammad Rị̣wān. Beyrouth : Dār al-kutub al'ilmiyya.

Bosworth, C.E. 1976. The Medieval Islamic Underworld. Leyde : Brill.

Combessie, Ph. 2004. Sociologie de la prison. Paris : La Découverte.

Cortese, D. et S. Calderini. 2006. Women and the Fatimids in the World of Islam. Edinburgh : Edinburgh University Press.

Crone, P. et M. Hinds. 1986. God's Caliph. Cambridge : Cambridge University Press.

Dick, I. 1961. «La passion arabe de S. Antoine Ruwah. » Le Muséon 74 : 109-33.

Donner, F.M. 1998. Narratives of Islamic Origins. Princeton : The Darwin Press.

Dozy, R. 1843. Dictionnaire détaillé des noms de vêtements chez les Arabes. Amsterdam : Jean Müller.

al-Fasawī. 1410 H. al-Ma'rifa wa'l-ta'rīkh, éd. Akram Diyā' al-'Umarī. Médine : Maktabat al-dār bi-l-Madīna 1-munawwara.

Hawting, G. 2000. The First Dynasty of Islam. The Umayyad Caliphate AD 661-750. Londres-New-York : Routledge.

\footnotetext{
${ }^{132}$ Al-Ṭabarī, Ta'rīkh al-rusul wal-l-mulūk, 8 : 604.

${ }^{133}$ Al-Ya 'qūbī, Ta'rīkh, éd. Khalīl al-Manșūr (Beyrouth : Dār al-kutub al-'ilmiyya, 2002), 2 : 322.

${ }^{134}$ Sur cette prison, voir Tillier, « Prisons et autorités urbaines » : 401-402.

${ }^{135}$ Ibn al-Jawzī, al-Muntazam, $8: 11$.
} 
Hentati, N. 2007. « La prison en Occident musulman médiéval. » Arabica 54 : 149-88.

Ibn Abī Shayba. 1409 H. al-Muṣannaf, éd. Kamāl Yūsuf al-Ḥūt. Riyad : Maktabat alrushd.

Ibn Hajar. 1998. Raf' al-iṣr 'an quḍāt Miṣr, éd. 'Alī Muhammad 'Umar. Le Caire: Maktabat al-Khānjī.

Ibn al-Jawzī. 1995. al-Muntazam, éd. Suhayl Zakkār. Beyrouth : Dār al-fikr.

Ibn Khallikān. 1994. Wafayāt al-a yān, éd. Iḥsān 'Abbās. Beyrouth : Dār Ṣādir.

Ibn Qutayba. 1994. 'Uyūn al-akhbār, éd. Muḥammad al-Iskandarān̄i. Beyrouth : Dār alkitāb al-'arabī.

-. s.d. al-Ma 'ārif, éd. Tharwat 'Ukāsha. Le Caire : Dār al-ma ārif.

Ibn Sa'd. 1968. al-Tabaqāt al-kubrā. Beyrouth : Dār Sādir.

Ibn Taghrī Birdī. 1930. al-Nujūm al-zāhira. Le Caire : Wizārat al-thaqāfa wa'l-irshād alqawmī.

al-Iṣfahān̄i. 1987. Maqātil al-Ṭālibiyìn, éd. Aḥmad Șaqr. Beyrouth : Mu'assasat al-a lāmī li-l-mațbū āt.

al-Jāḥiz. 1988. al-Bukhalā', éd. A. al- 'Awāmirī. Beyrouth : Dār al-kutub al- 'ilmiyya.

-. 1990. al-Bayān wa'l-tabyīn, éd. 'Abd al-Salām Hārūn. Tunis : Dār Saḥnūn.

Al-Khașșāf. 1978. Adab al-qā ḍ̂̀, éd. Farḥāt Ziyāda. Le Caire: The American University in Cairo Press.

al-Kindī. 1912. Akhbār quḍāt Miṣr. Dans Kitāb al-wulāt wa-kitāb al-quḍāt, éd. R. Guest. Leyde : Brill.

Lange, Ch. 2008. Justice, Punishment, and the Medieval Muslim Imagination. Cambridge : Cambridge University Press.

Libson, G. 2003. Jewish and Islamic Law. A Comparative Study of Custom During the Geonic Period. Cambridge : Harvard University Press.

Martel-Thoumian, B. 2006. «De l'équité à l'arbitraire : état des prisons et des prisonniers sous les derniers Mamlouks. » Annales Islamologiques 40 : 205-46.

al-Māwardī. 1983. Nasīhat al-mulūk, éd. Kh.M. Khiḍr. al-Ṣafāt : Maktabat al-falāḥ.

Mez, A. 1937. The Renaissance of Islam. Patna : Jubilee.

al-Mubarrad. 1997. al-Kāmil, éd. Muḥammad Aḥmad al-Dālī. Beyrouth : Mu'assasat alrisāla.

Northedge, A. 2005. The Historical Topography of Samarra. Londres : British School of Archaeology in Iraq - Fondation Max van Berchem.

Petry, C.F. 2003. «Al-Maqrīzī’s Discussion of Imprisonment and Description of Jails in the Khițaț. », Mamluk Studies Review 7 : 137-43.

Rosenthal, F. 1960. The Muslim Concept of Freedom Prior the Nineteenth Century. Leyde : Brill.

al-Ṣābi'. 1958. al-Wuzarā', éd. 'Abd al-Sattār Aḥmad Farāj. s.l. : Dār iḥyā' al-kutub al'arabiyya.

Sabra, A. 2000. Poverty and Charity in Medieval Islam. Mamluk Egypt, 1250-1517. Cambridge : Cambridge University Press.

Șāliḥ b. Aḥmad b. Hanbal. 1997. Sìrat al-Imām Aḥmad b. Hanbal, éd. Muḥammad alZaghlī. Beyrouth : al-Maktab al-islāmī.

al-Sarakhsī. 1406 H. al-Mabsūt. Beyrouth : Dār al-ma rifa. 
Schacht, J. 1950. The Origns of Muhammadan Jurisprudence. Oxford : Clarendon Press. Schneider, I. 1995. «Imprisonment in Pre-classical and Classical Islamic Law. » Islamic Law and Society 2 : 157-73.

Severus ben el-Moqaffa'. 1904. Historia Patriarcharum Alexandrinorum, éd. C.F. Seybold. Paris: Carolus Poussielgue.

al-Shāfi '̂̀. 1973. al-Umm, éd. Muḥammad Zuhrī al-Najjār. Beyrouth : Dār al-ma rifa.

al-Simnānī. 1984. Raw dat al-quḍāt wa-țarīq al-najāt, éd. Salāḥ al-Dīn al-Nāhī. BeyrouthAmman : Mu'assasat al-risāla-Dār al-furqān.

al-Șūlī. 1935. Akhbār al-Rāḍ̄ wa'l-Muttaqū, éd. J. Heyworth Dunne. Le Caire : al-Șāwī.

al-Ṭabarī. 1967. Ta'rīkh al-rusul wa'l-mulūk, éd. Muhammad Abū al-Faḍl Ibrāhīm. Le Caire : Dār al-ma'ārif.

al-Tanūkhī. 1971-73. al-Faraj ba'd al-shidda, éd. 'Abbūd al-Shāljī. Beyrouth.

al-Tawhīin̄. 1988. al-Baṣā'ir wa'l-dhakhā'ir, éd. Wadād al-Qāḍī. Beyrouth : Dār Șādir.

Tillier, M. 2002. Vies des cadis de Mișr. Le Caire : Ifao.

-. 2008. «Prisons et autorités urbaines sous les Abbassides. » Arabica 55 : 387-408.

-. À paraître. «Les prisonniers dans la société musulmane». Dans Vivre en société au Moyen Âge, éd. Malamut, E. et Ch. Raynaud. Aix-en-Provence : Presses Universitaires de Provence.

Wakī'. 1947-1950. Akhbār al-quḍāt, éd. 'Abd al- Azīz Muștafā al-Marāghī. Le Caire : Mațba'at al-sa'āda.

al-Ya qūbī. 2002. Ta'rīkh, éd. Khalīl al-Manșūr. Beyrouth : Dār al-kutub al- 'ilmiyya.

Zaman, M.Q. 2001. «Death, Funeral Processions, and the Articulation of Religious Authority in Early Islam. » Studia Islamica 93 : 27-58.

al-Ziriklī, H..-D. 1997. al-A 'lām. Beyrouth : Dār al-'ilm li-l-malāyīn. 